\title{
Keadilan Lingkungan Dalam Gerakan Perlawanan (Resistensi Masyarakat Adat Kasepuhan Bayah Terhadap PT. Cemindo Gemilang)
}

\author{
Wawan ${ }^{1}$ \\ Ilmu Pemerintahan, Fakultas Ilmu Sosial dan Ilmu Politik, \\ Universitas Sultan Ageng Tirtayasa. \\ wawansuper20@gmail.com \\ Khoirunisa ${ }^{2}$ \\ Program Studi Ekonomi Syariah, Fakultas Ekonomi dan Bisnis \\ Islam, Universitas Islam Negeri Sultan Maulana Hasanuddin \\ Banten \\ Khoirunisa049@gmail.com

\section{Nurul Patmah ${ }^{3}$} \\ Ilmu Pemerintahan, Fakultas Ilmu Sosial dan Ilmu Politik, \\ Universitas Sultan Ageng Tirtayasa. \\ nurulpatmah08@gmail.com
}

\section{E-ISSN 2721-0642}

Article Info
Recieved:
May 32021
Revised:
July 222021
Accepted:
July 292021
Doi Number
https://doi.org/10.37950/ijd.v3i2.103

\begin{abstract}
This paper will discuss the resistance movement of the Kasepuhan Bayah Indigenous Community against PT. Gemindo Gemilang. Simply put, this paper will be divided into two parts, first we will elaborate on the anxiety experienced by the Kasepuhan Bayah Indigenous People towards PT. Gemindo Gemilang. Second, it will be discussed about how the resistance movement was carried out. Theoretically, this paper rests on two main theories, namely the theory of social movements and the theory of environmental justice. both theories are considered to have strong relevance to the unit of analysis in this study so that they can dissect the case sharply and in depth. This study uses a descriptive qualitative method with data collection techniques through media observation and interviews. The results of this study explain that the Kasepuhan Bayah Indigenous Community is experiencing unrest by the construction and operational activities of the cement factory owned by PT. Cemindo Gemilang which destroys the environment. their cultural values which are very conservative towards nature make environmental issues quickly realized and become a shared responsibility. These issues include the loss of springs, polluted rivers, flooding, shipping mud, and marine pollution. This issue later became the basis of their resistance movement. The resistance movement is carried out directly by conducting demonstrations and planting trees continuously. Their consistency in this movement created a pattern of resistance that drew responses from many parties such as the general public and local media.
\end{abstract}

Keywords: environmental justice, resistance, indigenous peoples, PT. Gemindo Gemilang. 


\section{Abstrak}

Tulisan ini akan membahas gerakan perlawanan Masyarakat Adat Kasepuhan Bayah terhadap PT. Cemindo Gemilang. Sederhananya tulisan ini akan terbagi kedalam dua bagian, pertama kita akan elaborasi mengenai keresahan yang dialami oleh Masyarakat Adat Kasepuhan Bayah terhadap PT. Cemindo Gemilang. Kedua, akan dibedah tentang bagaimana gerakan perlawanan tersebut dilakukan. Secara teoritis tulisan ini bertumpu pada dua teori utama yakni teori gerakan sosial dan teori keadilan lingkungan (Environmental Justice). kedua teori tersebut dianggap memiliki relevansi yang kuat dengan unit analisa dalam penelitian ini sehingga dapat membedah kasus secara tajam dan mendalam. Penelitian ini menggunakan metode kualitatif deskriptif dengan teknik pengambilan data melalui observasi media dan wawancara. Hasil penelitian ini menjelaskan bahwa Masyarakat Adat Kasepuhan Bayah mengalami keresahan oleh aktifitas pembangunan dan operasional pabrik semen milik PT. Cemindo Gemilang yang merusak lingkungan. Nilai-nilai kultural mereka yang sangat konservatif terhadap alam membuat isu lingkungan dengan cepat disadari dan menjadi tanggung jawab bersama. Isu ini meliputi hilangnya mata air, sungai yang tercemar, banjir, lumpur kiriman, dan pencemaran laut. Isu ini kemudian menjadi basis dalam gerakan perlawanan mereka. Gerakan perlawanan dilakukan secara langsung dengan cara melakukan demonstrasi dan penanaman pohon secara terus menerus. Konsistensi mereka dalam gerakan ini menciptakan pola perlawanan yang menuai respon banyak pihak seperti masyarakat umum dan media-media lokal.

Katakunci: keadilan lingkungan, resistensi, masyarakat adat, PT. Cemindo Gemilang.

\section{Pendahuluan}

Kerusakan lingkungan merupakan konsekuensi logis dari pembangunan, terlebih jika pembangunan yang dilakukan bersifat eksploitatif. Kendati pembagunan sebuah perusahaan atau infrastruktur lainnya sudah diatur melalui Analisis Mengenai Dampak Lingkungan (AMDAL), namun degradasi lingkungan yang terjadi seakan merupakan keniscayaan. Pasalnya banyak perusahaan besar yang dinyatakan sesuai Analisis Mengenai Dampak Lingkungan (AMDAL), namun pada kenyataannya masih menimbulkan sejumlah persoalan serius yang akhirnya memicu resistensi dari masyarakat sekitar. Resistensi ini menjadi menarik untuk ditelaah karena kerap memiliki logika yang kompleks dan revolusioner, mengingat gerakan lingkungan memposisikan lingkungan sebagai subyek dan perjuangan yang dilakukan berdasar pada hak-hak lingkungan itu sendiri.

Seperti gerakan lingkungan oleh Masyarakat Adat Kasepuhan Bayah terhadap pembangunan korporasi yang bergerak dibidang produksi semen, menariknya gerakan mereka konsisten memperjuangkan lingkungan sebagai subjek yang melampaui konsep kepemilikan. Pabrik ini mengandalkan sumber daya alam sebagai bahan baku utama yakni gunung kapur di wilayah pegunungan Madur di Kecamatan Bayah, Kabupaten Lebak, Provinsi Banten. Pabrik semen dengan merk dagang Semen Merah 
Putih ini merupakan perusahaan hasil kerja sama antara Gama Group dengan Perusahaan Singapura. Pabrik ini dibangun dengan dana sebesar Rp7,8 Triliun. Perusahaan semen ini melakukan aktivitasnya diatas lahan seluas 3000 hektar (Seuhendra, 2015).

Sederhananya tulisan ini akan terbagi kedalam dua bagian, pertama kita akan elaborasi mengenai keresahan yang dialami oleh Masyarakat Adat Kasepuhan Bayah terhadap PT. Cemindo Gemilang. Bagian ini penting untuk dijelaskan karena gerakan yang dilakukan berangkat dari keresahan itu. Kedua, akan dibedah tentang bagaimana gerakan perlawanan tersebut dilakukan dalam konsep keadilan Lingkung (Environmental Justice). Disini penulis berusaha melihat bagaimana sistem sosial dan budaya yang dimiliki masyarakat adat bayah mengenali masalah khususnya pada isu lingkungan, hingga puncaknya menjadi sebuh gerakan perlawanan. Bagian ini menjadi penting karena disampaikan oleh Tarrow, dkk bahwa tanpa memahami nilai-nlai budaya, norma dan atribut sosial sebuah komunitas maka gerakan yang mereka lakukan akan sulit dimengerti (McAdam, Doug, Sidney Tarrow, 2002).

Hindrati dalam situs Aliansi Masyarakat Adat Nusantara (aman.or.id) menyampaikan bahwa sejak pabrik semen itu berdiri di tanah Bayah, kerusakan lingkungan mulai dirasakan seperti hilangnya mata air bagi lebih dari 600 Kepala Keluarga (KK) di Cipicung, Kampung sawah (Hindrati, n.d.). Dikutip juga dari merahputih.com, bahwa hilangnya mata air di daerah resapan tersebut disebabkan oleh pemasangan tiang Conveyor di area mata air sehingga sumber air menjadi hilang dan ekosistem disekitarnya terganggu (Flo, 2019).

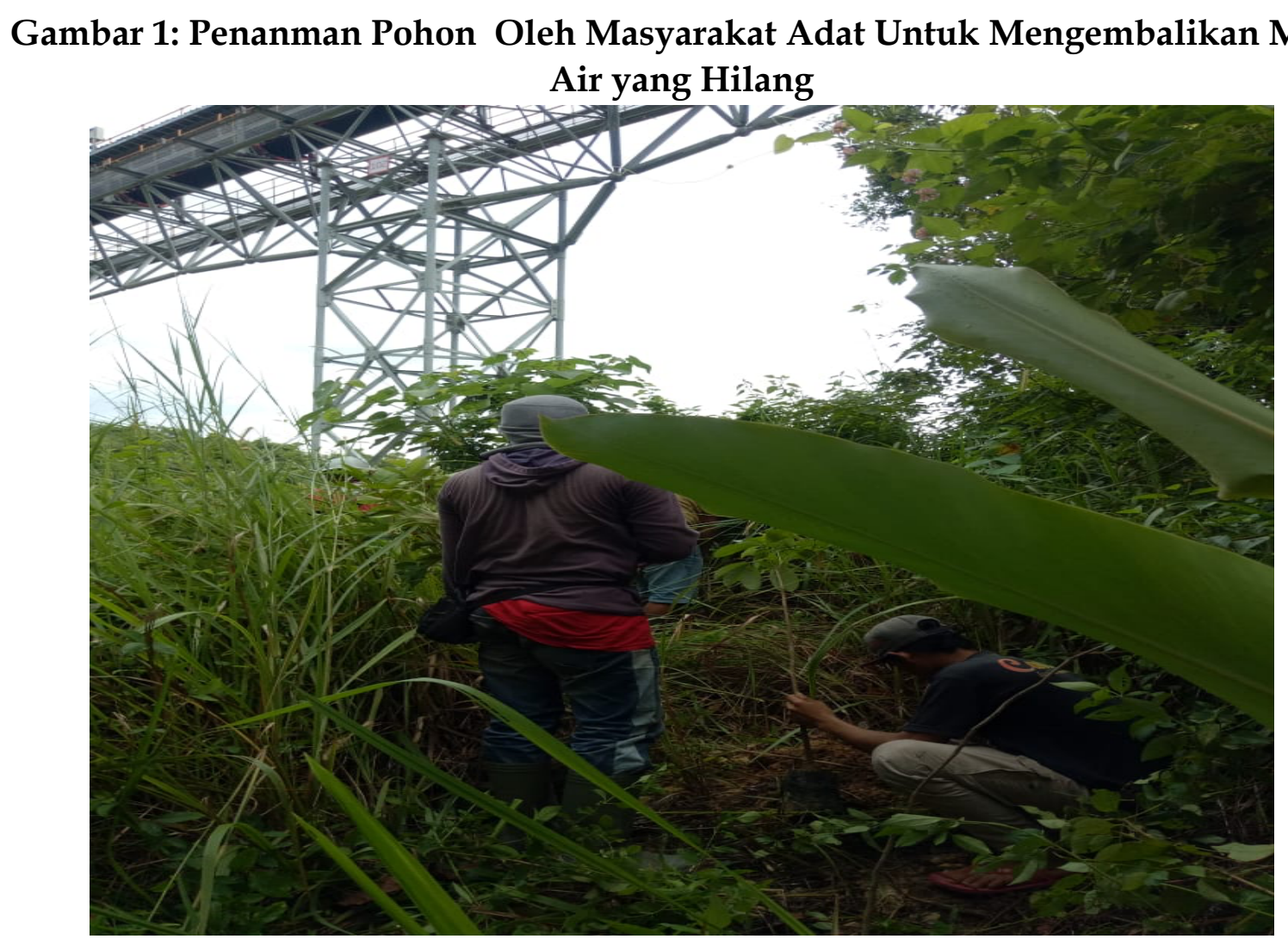

Sumber: (Flo, 2019) 
Kemudian kerusakan lingkungan yang terjadi di kawasan pabrik ini juga berimbas pada masyarakat sekitar berupa lumpur kiriman dan tanah longsor serta banjir. Rentetan keadaan ini merupakan bukti paling nyata bahwa kerusakan lingkungan memang serius terjadi disana. Namun kita tidak akan membahas bagaimana protes dari masyarakat sekitar yang menuntut hak mereka atas kerugian karena rusaknya lingkungan. Melainkan kita akan fokus pada perjuangan Masyarakat Adat Kasepauhan Bayah dalam melakukan perlawanan terhadap korporasi untuk membela kelestarian lingkungan.

Dalam riset ini penulis mengacu pada beberapa penelitian sejenis yang pernah dilakukan dan menghasilkan temuan menarik. Atas dasar temuan-temuan itulah penulis juga menemukan novelty dalam riset ini, diantaranya penelitian ini mengacu pada hasil penelitian Monalu terhadap perlawanan masyarakat Batak kepada PT. Indorayon yang mampu menghasilkan gerakan yang massif dan kuat dalam memperjuangkan isu-isu lingkungan, dalam bingkai lokal gerakan masyarakat batak ini terjadi secara massif hingga mampu menghentikan perusahaan raksasa tersebut berhenti beroperasi dan kahirnya mampu mendorong kebijakan pemerintah yang lebih baik bagi kelestarian lingkugan (Monalu, 2007). Lalu penelitian Regus mengungkapkan bahwa aktifitas pertambangan di Manggarai NTT sama sekali tidak mengindahkan kelestarian lingkungan sehingga memicu resistensi dari masyarakat sekitar terhadap perusahaan hingga menimbulkan konflik, dalam kasus ini masyarakat menuntut perusahaan agar bertanggung jawab atas rusaknya lingkungan yang merugikan masyarakat (Regus, 2011). Kemudian penelitian lainnya dilakukan oleh Ramadhan tentang gerakan sosial masyarakat di Rumpin dalam memperjuangkan hak milik tanah mereka yang diklaim oleh pihak TNI AU, hasilnya ia mengemukakan bahwa gerakan dilakukan secara massif dan nilai-nilai kolektifitas masyarakat lokal mampu merawat gerakan terebut sehingga perjuangan menjadi kian kuat (Ramadhan, 2018).

\section{Kerangka Teori}

\section{Gerakan Sosial Dalam Konsep Perlawanan}

Menurut Tarrow gerakan sosial dapat dipahami sebagai politik perlawanan yang digalang oleh masyarakat dengan atau tanpa kerja sama dengan kelompok masyarakat lain untuk melawan pihak yang memeliki power dan otoritas yang signifikan, biasanya mereka adalah kalangan elite (Tarrow, 1998). Sedangkan menurut Anthony Giddens dalam (Fadilah putra, 2006) gerakan sosial diistilahkan secara sederhana sebagai tindakan kolektif (Colective Action), artinya gerakan sosial dipahami sebabagai aksi bersama untuk tujuan tertentu melalui tindakan yang terarah namun tindakan ini dirawat diluar organisasi yang mapan. Diperkuat oleh Mirsel yang mengungkapkan bahwa gerakan sosial merupakan tindakan kolektif yang bersumber dari keyakinan sekelompok orang dan dilakukan dengan tujuan untuk menghalangi perubahan dalam lingkungan sekitarnya (Mirsel, 2004).

Kemudian Tarrow juga mengungkapkan dalam sebuah gerakan sosial terjadi artikulasi isu yang akan menentukan gerakan sosial seperti apa yang akan dilakukan. 
proses ini sederhananya disebut Pembingkaian (Framing). Dengan Pembingkaian (Framing) ini proses mobilisasi masa terjadi, karena individu-individu akan melakukan justifikasi dan memahami sebuah isu sebagai sesuatu yang penting dan membutuhkan gerakan bersama. Tarrow menyebut bahwa Pembingkaian (Framing) ini meliputi tiga hal yaitu: Agregate Frame, yakni proses dimana masalah diartikan sebagai isu bersama dan tiap-tiap individu menyadari bahwa tindakan mereka dibutuhkan dalam gerakan. Kemudian ada Konsensus Frame, yaitu proses dimana persoalan didefinisikan dan individu-individu terlibat dalam emosional yang sama untuk menentukan gerakan. Selanjutnya adalah Colective Action Frame adalah keadaan dimana individu-individu mulai menentukan arah gerakan, dengan bertumpu pada urgensi atas isu yang sudah disepakati tadi, pada bagian ini gerakan dilakukan.

Masih bertumpu pada pendapatnya Tarrow (1988), yang menyampaikan bahwa gerakan sosial memiliki beberapa komponen yaitu:

a. Struktur: menurut Tarrow bagian ini menjadi penting karena gerakan sosial melibatkan mobilisasi yang akan menjadi lebih mudah ketika terdapat struktur yang terbuka, dengan adanya struktur yang luwes maka tindakan kolektif dapat lebih terorganisir dan menjadi lebih terarah. Namun struktur ini haruslah horizontal dan tidak terdapat hirarkis.

b. Tantangan Kolektif (Colective Challenge): bagian ini merupakan objek perlawanan gerakan, dalam gerakan langsung tantangan bisa berupa para elite sebagai pihak yang mereka lawan, pihak berwenang, atau pihak lainnya. Adanya Tantangan juga ditandai dengan terjadinya perlawanan, tindakan menghalangi serta menciptakan suasana ketidak pastian atas tindakan pihak lain yang mereka lawan.

c. Tujuan Bersama: secara individual memang akan terdapat alasan yang kompleks mengapa individu akhirnya memutuskan untuk bergabung dalam gerakan. Namun dalam sebuah tindakan bersama ada narasi besar yang mengakomodasi tujuan tiap-tiap individu yang akhirnya menciptakan klaim bersama dalam gerakan yang dilakukan.

d. Solidaritas dan Identitas Kolektif: gerakan sosial terjadi salah satunya karena ada identitas kolektif dan solidaritas yang membingkai komunitas atau kelompok sosial yang melakukan gerakan. Kolektifitas dan identitas ini biasanya berangkat dari etnisitas, agama, nasionalisme, Isu lingkungan, HAM, gender, dan lain-lain.

e. Memelihara politik perlawanan: artinya, sebuah gerakan sosial harus dirawat secara konsisten proses perjuangan dan perlawanannya. Konsitensi ini akan menjadikan gerakan sosial menjadi kuat dan berpengaruh.

\section{Konsep Keadilan Lingkungan (Environmental Justice)}

Secara teoritis, diskursus mengenai keadilan lingkungan muncul seiring dengan massifnya pembahasan tentang lingkungan dalam konteks sosial dan akademis. Keadaan ini kemudian memicu gerakan sosial dari masyarakat yang fokus melihat 
ketidakadilan terhadap lingkungan (Taylor, 2000). Secara lebih rigid Taylor membagi prinsip keadilan lingkungan menjadi beberapa bagian diantaranya:

a. Prinsip Ekologis

Prinsip ini akrab juga dengan apa yang disebut Ecosentris. Sederhananya prinsip ini berkeyakinan bahwa alam adalah subjek yang harus mendapatkan haknya untuk terus lestari, sehingga menuntut tanggung jawab dari manusia terhadap alam. Aktifitas manusia yang memiliki konsekuensi merusak alam adalah isu yang yang banyak dibahas dalam prinsip ini seperti pengelolaan tanah, penghematan energy, pengelolaan limbah dan lainnya.

b. Prinsip Keadilan

Prinsip ini melihat bahwa alam adalah sumberdaya yang penting, sehingga penggunaanya harus dilakukan dengan penuh pertimbangan. Kesedian sumberdaya bagi generasi dan masa depan juga harus mendorong kebijakan yang dapat mempertegas pengendalian lingkungan. Pada dasarnya prinsip ini menghendaki semua aktifitas manusia harus memiliki pertimbangan terhadap kelestarian alam dan mencegahnya pada kehancuran ekologi.

Senda dengan konsep ini teori politik lingkungan juga memiliki konsep yang relevan dengan kedua prinsip keadilan lingkungan. sebagaimana disampaikan oleh Siahaan bahwa politik lingkungan merupakan alat untuk memahami konsep kepemilikan, kontrol, akses, dan pengelolaan sumber daya dengan memperhatikan kesehatan lingkungan dan keberlanjutannya (Siahaan, 2020). Sedangkan Julian Steward dalam (Robbins, 2012) mengungkapkan perspektif politik lingkungan dalam bingkai peran budaya. Dimana menurut Steward budaya memili peran yang sangat besar dan penting dalam mempengaruhi prilaku masyarakat dalam relasinya dengan lingkungan. Menurutnya setiap kebudayaan memiliki orientasi nilai, konsep kepemilikan, ritual, struktur, simbol, hingga mitos yang bertumpu terhadap alam.

Riset ini berpegang pada beberapa penelitian sejenis yang pernah dilakukan diantaranya hasil penelitian Monalu terhadap perlawanan masyarakat Batak kepada PT. Indorayon yang mampu menghasilkan gerakan yang massif dan kuat dalam memperjuangkan isu-isu lingkungan, dalam bingkai lokal gerakan masyarakat batak ini terjadi secara massif hingga mampu menghentikan perusahaan raksasa tersebuty berhenti beroperasi dan kahirnya mampu mendorong kebijakan pemerintah yang lebih baik bagi kelestarian lingkugan (Monalu, 2007). Lalu penelitian Regus mengungkapkan bahwa aktifitas pertambangan di Manggarai NTT sama sekali tidak mengindahkan kelestarian lingkungan sehingga memicu resistensi dari masyarakat sekitar terhadap perusahaan hingga menimbulkan konflik, dalam kasus ini masyarakat menuntut perusahaan agar bertanggung jawab atas rusaknya lingkungan yang merugikan masyarakat (Regus, 2011). Kemudian penelitian lainnya dilakukan oleh Ramadhan tentang gerakan sosial masyarakat di Rumpin dalam memperjuangkan hak milik tanah mereka yang diklaim oleh pihak TNI AU, hasilnya ia mengemukakan bahwa gerakan dilakukan secara massif dan nilai-nilai kolektifitas masyarakat lokal mampu merawat gerakan terebut sehingga perjuangan menjadi kian kuat (Ramadhan, 2018). 
Kemudian riset wilujeng 2017, mengungkapkan bahwa gerakan sosial yang tendensius melawan norma, melampaui identitas gender dan peran sosial yang normal juga sangat dipengaruhi oleh nilai-nilai kultural yang melatari setiap individu dalam kelompok gerakan tersebut (Wilujeng, 2017). Senada dengan ini, penelitian Andreas Jefri Deda dan Suriel Semuel Mofu tentang masyarakat adat di papua barat, menunjukan bahwa nilai-nilai kultural adalah tumpuan utama dalam mengatur sikap seseorang untuk berinterkasi secara seimbang dengan alam maupun dengan sesamanya (Andreas jefri deda, 2014).

\section{Metode Penelitian}

Penelitian ini menggunakan metode penelitian kualitatif deskriptif dimana data primer diperoleh dari hasil observasi dan wawancara Sedangkan data sekunder diperoleh dari informasi yang dimuat di media masa, artikel, jurnal ilmiah dan dokumen skripsi (Moleong, 2012).

Data yang telah diperoleh kemudian diolah melalui rangkaian metode yang ditentukan lalu meninjaunya berdasarkan sudut pandang teori yang melibatkan analisis mendalam dari penulis. Kemudian data disajikan secara deskriptif argumentatif pada bagian pembahasan.

\section{Hasil dan Diskusi}

\section{Keresahan dan Isu Gerakan Masyarakat Adat Bayah}

Masyarakat Adat Kasepuahan Bayah merupakan entitas masyarakat yang tergabung berdasarkan ikatan kultural. Mereka memiliki identifikasi yang kuat terhadap alam disekitarnya. Beberapa wilayah bahkan diyakini sebagai tempat sakral dan menjadi bagian dari keluhuran budaya mereka. Secara prinsipil mereka menempatkan alam sebagai bagian dari mereka yang harus dijaga dan dilestarikan. Mereka juga sangat menentang pengrusakan terhadap alam karena melihat bahwa alam dapat memberi kehidupan bagi manusia dan makhluk hidup lainnya tanpa harus melakukan eksploitasi.

Nilai kultural ini menyulut keresahan luar biasa ketika sebuah mega korporasi dengan anggaran pembangunan mencapai Rp7,8 Triliun dibangun diatas tanah seluas 3000 Hektare (Suhendra, 2015). Keresahan ini bukan tanpa alasan, pasalnya lahan yang dijadikan tempat pembangunan pabrik semen oleh PT. Cemindo Gemilang adalah wilayah perbukitan dan hutan yang oleh Masyarakat Adat Kasepuhan Bayah diyakini sebagai tempat yang amat sakral. Dalam keyakinan lokal mereka tempat tersebut adalah hutan larangan dan dipercaya tempat bersemayanya arwah para leluhur mereka. Sehingga merusak tempat tersebut dapat menimbulkan kehancuran yang serius bagi ekologi dan tatanan budaya mereka.

“Da muhun tibaheula ogeh nya kapercayaan didieu mah janten kuat sangkan gunung madur teh tempat ngancik karuhun tidieu... Ulakan diruksak jiga ayeuna kitu, motongken daun na oge pantang." "Ya begitulah kepercyaan masyarakat disni sangat kuat bahwa gunung madur adalah tempat 
tinggal para leluhur kami... jangankan dirusak seperti sekarang dulu memetik ranting disana saja bagi kami pantangan besar." (AS. 52 th. Masyarakat Adat Kasepuhan Bayah. wawancara 3 Juni 2020).

\begin{abstract}
"Ayeuna mah pan pirempaneun kusabab larangan diruempak, alam tos rusak, cai jadi kiruh, leweng jadi eweuh, gunung jadi rata, akibatna bahaya teu tiasa dibendung. Kukitu na kami masyarakat adat didieu tetep boga kawajiban ngajaga alam sabisa-bisa." "sekarang sangat mengkhawatirkan, karena pantangan tidak dihiraukan, alam rusak, sungai jadi keruh, hutang jadi hilang, gunung jadi rata, akibatnya bahaya tidak bisa dibendung. Meskipun demikian kami selaku pemangku adat disini tetap memiliki kewajiban untuk menjaga alam semampu kami." (EN. 57 th. Masyarakat Adat Kasepuhan Bayah. wawancara 3 Juni 2020).
\end{abstract}

Jadi keresahan pertama yang dirasakan oleh masyarakat adat bayah adalah aktifitas pembangunan dan opersional pabrik semen yang bertentangan dengan nilai kultural mereka yang sangat koservatif terhadap alam. Keresahan ini kian menjadi ketidak kerusakan demi kerusakan fatal terjadi pada lingkungan yang selama ini mereka sakralkan dan mereka jaga. Senada dengan ini, Penelitian Nita Safitri mengungkapkan bahwa pembangunan PT. Frepot tidak mengindahkan kelestarian lingkungan dan perubahan sosial disekitarnya yang kemudian menghasilkan pertentangan dan perlawanan dari suku Amugme (Safitri, 2011).

Keresahan ini bukan tanpa alasan, namun memiliki implikasi yang konkrit, pasalnya menurut Hindrati (2019) dalam situs resmi Aliansi Masyarakat Adat Nusantara (AMAN) salah satu kerusakan lingkungan di kawasan pabrik semen milik PT. Cemindo Gemilang adalah hilangnya mata air bagi yang selama ini telah memenuhi kebutuihan air bersih bagi lebih dari 600 kepala keluarga di perkampungan sekitar area pabrik. Ditambah pembangunan pelabuhan bagi kapal pengangkut material semen telah mengurug wilayah tangkap ikan nelayan. Juga beberapa kampung kerap mengalami banjir bandang dan lumpur kiriman dari aktifitas pabrik.

Jadi keresahan masyarakat adat bayah terhadap kerusakan lingkungan bersandar pada keyakinan kultural mereka yang sangat konservatif terhadap alam. Keresahan ini akhirnya mengartikulasi isu-isu kerusakan lingkungan seperti hilangnya mata air, banjir bandang, laut tercemar, hingga polusi udara yang dipahami bersama sebagai narasi perlawanan terhadap korporasi. keadan ini senada dengan apa yang disampaikan oleh Mirsel (2004) tentang gerakan sosial yang mengungkapkan bahwa gerakan sosial merupakan tindakan kolektif yang bersumber dari keyakinan sekelompok orang dan dilakukan dengan tujuan untuk menghalangi perubahan dalam lingkungan sekitarnya. Lebih spesifik pada konteks perlawanan, Tarrow (1998) mengungkapkan bahwa pada intinya gerakan sosial adalah politik perlawanan oleh sekelompok masyarakat terhadap pihak yang memiliki kekuatan atau kewenangan.

Fase yang oleh Tarrow disebut pembingkaian (Framing) dalam kasus ini dipengaruhi oleh perspektif kultural terhadap alam yang dengan mudah membuat isu terhadap lingkungan disadari oleh seluruh masyarakat adat sebagai isu dan tanggung jawab bersama bersama. Keadaan ini membuat keresahan masyarakat menjadi lebih cepat disadari dan diartikulasi dalam isu-isu lingkungan seperti yang telah dijelaskan diatas. jadi keresahan masyarakat adat kasepuhan bayah terhadap PT. Cemindo Gemilang berangkat dari aktifitas pembangunan pabrik dan opersional pabrik yang 
eksploitatif, kerusakan lingkungan menuai sensitifitas dari masyarakat adat karena wilayah yang rusak adalah tempat yang disakralkan oleh mereka. Isu yang menjadi tumpuan dalam gerakan mereka fokus pada perjuangan keadilan lingkungan seperti hilangnya mata air, hilangnya wilayah tangkap ikan nelayan, rusaknya hutan, banjir bandang, lumpur kiriman dan polusi udara. Keresahan dan isu tersebut kemudian dikolektif sebagai tanggung jawab bersama.

\section{Gerakan Perlawanan Dalam Isu Keadilan Lingkungan}

Masyarakat Adat Kasepuhan Bayah melakukan gerakan perlawanan terhadap PT. Cemindo Gemilang dengan menarasikan isu-isu lingkungan sebagai basis utama gerakan. Dalam aktualisasinya mereka secara langsung dan terbuka menentang aktifitas pabrik yang menyebabkan kerusakan pada lingkungan. Sistem kultural mereka yang cenderung tradisional menghasilkan gerakan langsung. Seperti melakukan demonstrasi disekitar pabrik dan melakukan penanaman pohon kembali di wilayah pabrik yang sudah rusak. Menariknya respon dari PT. Cemindo Gemilang yang tidak merespon tuntutan mereka justru membuat gerkakan perlawanan dilakukan kian massif dan konsisten. Seperti gerakan penanaman pohon di wilayah opersional pabrik yang terus menerus dilakukan meskipun selalu dihancurkan kembali oleh pihak perusahaan. Selaras dengan ini penelitian Harmanto, dkk. Menyampaikan bahwa gerakan sosial masyarakat di Kendeng dalam menentang berdirinya pabrik semen juga dilakukan dengan nuansa perlawanan yang kentara, seperti melakukan aksi pengecoran kaki dan menggalang demonstrasi besar disekitar pabrik (Rizky agus harnanto, Atika ishmatul ummah, Elsya rekavianti, 2018).

Untuk melawan aktifitas pabrik yang menyebabkan kerusakan lingkungan seperti hilangnya mata air, banjir, polusi udara dan lumpur kiriman, mereka melakukan gerakan menanam pohon yang secara konsisten dilakukan terus menerus meskipun selalu dihancurkan kembali oleh pihak pabrik. Namun mereka meyakini bahwa perjuangan dalam mengembalikan fungsi alam adalah tanggung jawab mereka sebagai masyarakat adat. Keadaan ini menggambarkan apa yang disampaikan Taylor (2000) bahwa gerakan lingkungan muncul sebagai reaksi dari ketidakadilan lingkungan yang kemudian disadari oleh masyarakat sebagai tanggung jawab bersama. Keadaan inilah yang terjadi pada Masyarakat Adat Bayah yang menyadari ketidakadilan lingkungan oleh aktifitas korporasi.

\section{Gambar 2: Penanaman Pohon Kembali oleh Masyarakat Adat}

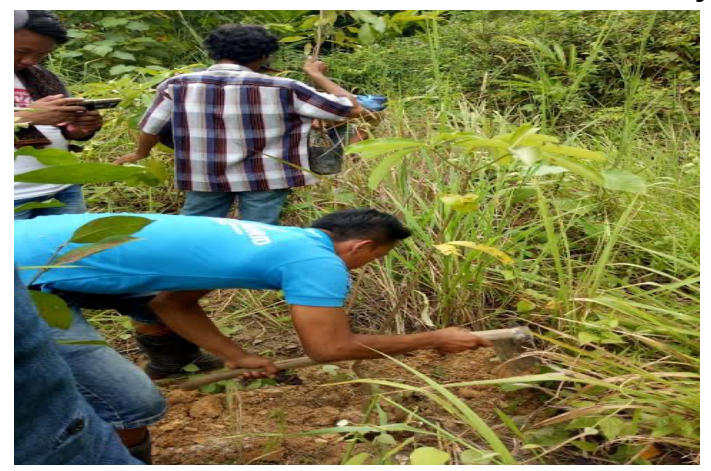

Sumber: (Nonstopnews, 2019) 
Dalam perlawanan ini masyarakat adat menghendaki agar pabrik lebih memperhatikan keadilan lingkungan. Gerakan menanam pohon dimaknai sebagai upaya mengembalikan fungsi hutan juga sebagai perlawanan terhadap aktifitas pabrik yang merusak alam. Secara prinsipil gerakan perlawanan mereka senada dengan apa yang disampaikan Taylor (2000) tentang prinsip ekologis dalam keadilan lingkungan, dimana prinsip itu menghendaki adanya tanggung jawab terhadap alam dalam setiap aktifitas manusia dan memperhatikan keseimbangan alam dengan pembangunan. Prinsip ini juga diadopsi oleh masyarakat lain dalam gerakan sejenis misalnya temuan Ismanto tentang gerakan masyarakat adat sami yang menciptakan konsep dan pola gerakan perlawanan berbasis keadilan lingkungan dan sosial, hasilnya mereka melakukan resistensi cukup kuat terhadap proyek pemerintah yang merusak lingkungan dan identitas sosial mereka, gerakan langsung terlihat dengan tetap konsistennya mereka merawat gerakan (Ismanto, 2017).

"henteu paduli eta tangkal anu dipelak bade dicabut, nu pasti kami bakal terus ngalakuken gerakan melak tangkal sakebel leweng kami dirusak, cai hulu kami lengit, da kudu kitu tanggung jawab anu diamanatken karuhun the." "tidak peduli pohon yang kami tanam akan dicabut, yang pasti kami akan terus menanam untuk hutan kami, untuk mengembalikan mata air kami karena begitu amanat dari leluhur kami." (SM. 46 th. Masyarakat Adat Kasepuhan Bayah. wawancara 3 Juni 2020).

“...salila ieu duka tos sabaraha kali masyarakat adat melakan tatangkalan didaerah eta, setiap dicabutku pihak pabrik lajeng dipelakan deui, kitu jeng kitu bae, tapi kami moal sampe eren mah." "selama ini entah sudah berapa kali masyarakat adat melakukan penanaman pohon kembali di wilayah itu, setiap dicabut oleh pihak pabrik, kami langsung tanami lagi, begitu terus-menerus." (BS. 61 th. Masyarakat Adat Kasepuhan Bayah. wawancara 3 Juni 2020).

Dalam perjalanannya ternyata gerakan menanam pohon yang dilakukan oleh masyarakat adat kasepuhan bayah menuai respon yang tidak koperatif dari pabrik. Kerap pohon yang mereka tanam dicabut dan dirusak karena dianggap berada pada wilayah pabrik. Namun keadaan ini membuat perlawanan mereka menjadi konsisten dan dilakukan berulang kali sebagai bentuk perjuangan bagi keadilan lingkungan. Meskipun hingga hari ini perjuangan mereka belum menemui titik temu namun mereka mengakui bahwa perlawanan tidak akan berhenti selagi pabrik tidak memperhatikan kelestarian lingkungan.

Gerakan mereka juga mendapatkan dukungan dari masyarakat diluar masyarakat Bayah, karena beberapa isu yang diperjuangkan dalam perlawanan tersebut juga menyangkut kepentingan masyarakat umum. Seperti hilangnya mata air 
yang membuat lebih dari 600 kepala kepala keluarga kehilangan akses terhadap air bersih. Dukungan dari masyarakat terlihat dari peran mereka dalam membantu mengangkat gerakan perlawanan masyarakat adat ke media-media lokal. Alhasil dalam observasi digital di media lokal, kita bisa menemukan beberapa dokumentasi dan berita ataupun artikel yang memuat bagaimana masyarakat adat Bayah berjuang dalam menyuarakan keadilan lingkungan. Selain itu juga banyak pihak yang mendukung mulai dari masyarakat biasa disekitar Bayah, pasalnya masyarakat akhirnya menyadari bahwa gerakan perlawanan tersebut bertumpu pada rasionalitas yang kokoh bagi keadilan lingkungan dan keberlanjutan masyarakat sekitar. Keadaan ini kemudian juga diperkuat oleh Fhatoni, dkk. Dalam temuanyya bahwa gerakan perlawanan masyarakat di pulau batang telah mengerahkan perlawanan fisik yang kentara, hingga akhirnya terjadi respon yang baik dari masyarakat setempat karena kesadaran khalayak terjadi berkat gerakan yang mereka lakukan sehingga membuat gerakan mereka terjadi dalam tim yang lebih besar dan kuat (Alief khahfi fhatoni, Purwoko, 2017).

\section{Gambar 3: Gerakan Menanam Pohon Mendapatkan Dukungan Dari Masyarakat dan} Jurnalis Lokal

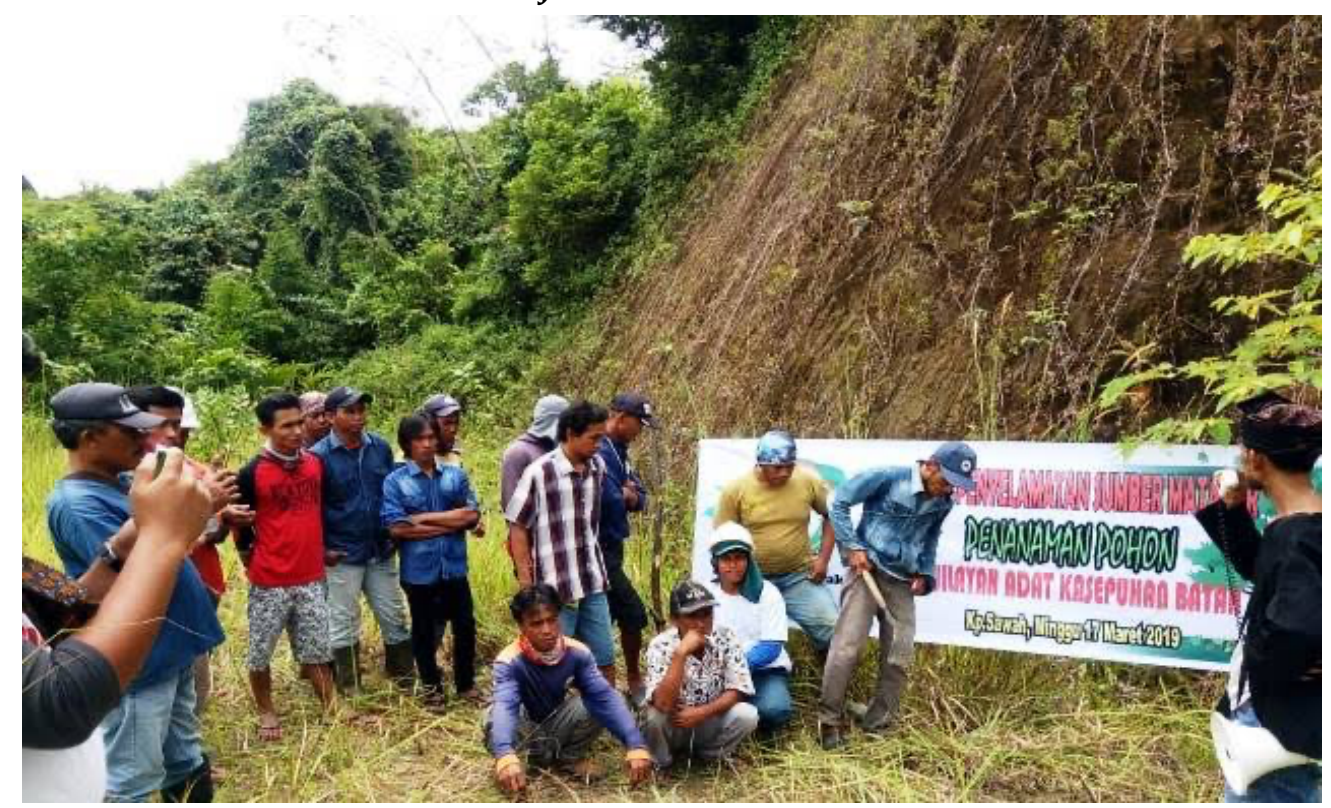

Sumber: Nonstopnews (2019)

Gerakan perlawanan Masyarakat Adat Kasepuhan Bayah yang secara konsisten dilakukan untuk memperjuangkan keadilan lingkungan melalui gerakan menanam pohon telah menuai dukungan dari masyarakat lain yang melihat gerakan ini sebagai perjuangan yang penting. Pasalnya apa yang dilakukan masyarakat adat menyangkut kelestarian alam yang tentunya dibutuhkan oleh generasi masa depan. Keadaan ini senada dengan apa yang dissampaikan Taylor (2000) tentang prinsip keadilan dalam Environmental justice bahwa pertimbangan besar harus dilakukan untuk kelestarian alam dan mencegahnya dari kerusakan ekologi, karena keadaan ini dibutuhkan untuk masa depan dan generasi yang akan datang. 
Dalam aksi yang lebih panjang, gerakan ini bukan tidak mungkin menimbulkan konflik, pasalnya respon dari korporasi justru tidak mengakomodasi kepentingan masyarakat adat, seperti yang terjadi dengan masyarakat adat sunda wiwitan yang akhirya mereka harus tergusur di tanah adatnya sediri setelah melakukan konflik berkepanjangan dengan perusahaan, bahkan hingga saat ini konflik tersebut belum menemukan resolusinya (Rachel farakhiyah, 2019). Dalam keadaan ini, apa yang terjadi pada masyarakat Bayah juga sedang mengarah pada keadaan konflik yang benar-benar konfliktual karena respon dari pihak korporasi tidak memperlihatkan sikap yang kooperatif terhadap tuntutan masyarakat adat. Keadan ini juga berpotensi gerakan mereka mengalami kegagalan. Seperti hasil temuannya Hirzan dan Hasanudin yang membahas tentang gerakan sosial masyarakat Adat Di Kecamatan Peranap Kabupaten Indragiri Hulu yang akhirnya mengalami kegagalan karena beberapa tantangan seperti respon tidak kooperatif dari perusahaan, fokus gerakan yang kabur dan tidak menyeluruh, hingga tidak adanya respon dari pemerintah desa (Adli Hirzan, 2017).

Jadi gerakan perlawanan Masyarakat Adat Kasepuhan Bayah dilakukan secara langsung dengan cara melakukan penanaman pohon di wilayah yang dulunya adalah hutan yang mereka jaga. Selain itu juga mereka aktif melakukan aksi demonstrasi terhadap PT. Cemindo Gemilang. Gerakan mereka dilakukan dengan penuh tanggung jawab yang bertumpu pada nilai-nilai kultural yang dimiliki. Menariknya gerakan ini konsisten dilakukan meskipun berulang terjadi rekasi yang tidak koperatif dari pihak pabrik, namun konsistensi inilah yang kemudian menjadi bentuk perlawanan mereka. Rasa tanggung jawab sebagai masyarakata adat ternyata telah membentuk kesadaran mereka untuk terus menjaga keseimbangan alam. Dalam gerakannya mereka menuntut agar pihak pabrik lebih bertanggung jawab dan memperhatikan kelestarian lingkungan disekitar. Keseimbangan alam dan industri menurut mereka adalah aspek yang seharusnya bisa berdampingan.

\section{Kesimpulan}

Masyarakat Adat Kasepuhan Bayah mengalami keresahan oleh aktifitas pembangunan dan operasional pabrik semen milik PT. Cemindo Gemilang yang merusak lingkungan. Nilai-nilai kultural mereka yang sangat konservatif terhadap alam membuat isu lingkungan dengan cepat disadari dan menjadi tanggung jawab bersama. Isu ini meliputi hilangnya mata air, sungai yang tercemar, banjir, lumpur kiriman, dan pencemaran laut. Isu ini kemudian menjadi basis dalam gerakan perlawanan mereka.

Gerakan perlawanan dilakukan secara langsung dengan cara melakukan demonstrasi dan penanaman pohon secara terus menerus. Konsistensi mereka dalam gerakan ini menciptakan pola perlawanan yang menuai respon banyak pihak seperti masyarakat umum dan media-media lokal.

\section{Tentang Penulis}

Wawan, merupakan mahasiswa Ilmu Pemerintahan, Fakultas Ilmu Sosial dan 
Ilmu Politik Universitas Sultan Ageng Tirtayasa. Tertarik terhadap kajian gerakan sosial dan citizenship.

Khoirunisa, merupakan mahasiswa Fakultas Ekonomi dan Bisnis Islam, Universitas Sultan Maulana Hasanuddin Banten. Tertarik terhadap kajian pembangunan, ekonomi politik dan masyarakat sipil.

Nurul Patmah, merupakan mahasiswa Ilmu Pemerintahan, Fakultas Ilmu Sosial dan Ilmu Politik Universitas Sultan Ageng Tirtayasa. Tertarik terhadap kajian masyarakat adat, Gerakan Sosial, Pelayanan Publik dan lingkungan.

\section{Ucapan Terimakasih}

Penulis mengucapkan terimakasih kepada M. Dian Hikmawan, M.A yang telah membimbing penulis hingga penelitian ini dapat terselesaikan. Terimakasih kepada Masyarakat Adat Kasepuhan Bayah yang telah berkontribusi secara koperatif dalam memberikan informasi yang dibutuhkan dalam penelitian ini. terimakasih kepada Prodi Ilmu Pemerintahan FISIP Untirta dan smua pihak yang berperan dalam penelitian ini.

\section{Referensi}

Adli Hirzan, H. (2017). Gerakan Masyarakat Dalam Membentuk Kenegerian Tiga Lorong Baturijal Hulu Sebagai Desa Adat Di Kecamatan Peranap Kabupaten Indragiri Hulu Tahun 2014-2015. JOM FISIP, 4.

Alief khahfi fhatoni, Purwoko, N. hidayat sardini. (2017). Perlawanan Masyarakat Luar Batang Jakarta Terhadap Kebijakan Revitalisasi Kawasan Pesisir Pada Tahun 2016. EJournalUndip.

Andreas jefri deda, S. semuel mofu. (2014). Masyarakat Hukum Adat Dan Hak Ulayat Di Provinsi Papua Barat Sebagai Orang Asli Papua Di Tinjau Dari Sisi Adat Dan Budaya; Sebuah Kajian Etnografi Kekinian. JURNAL ADMINISTRASI PUBLIK, 11.

Fadilah putra, D. (2006). Gerakan Sosial. Averoes Press.

Flo, E. (2019). Pabrik Semen Rusak Mata Air, Masyarakat Adat Kasepuhan Banten Kidul Desak Peninjauan Ulang Izin. Merahputih.Com. https:/ / merahputih.com/post/read/rusak-mata-air-masyarakat-adat-kasepuhanbanten-kidul-desak-pabrik-semen-ditinjau-ulang

Hindrati, E. (n.d.). Pabrik Semen yang Merusak Lingkungan Masyarakata Adat yang Merawat Lingkungan. Aliansi Masyarakat Adat Nusantara. aman.or.id/2019/05/Pabrik Semen yang Merusak Lingkungan Masyarakata Adat yang Merawat Lingkungan

Ismanto, M. (2017). Gerakan Masyarakat Adat Sami Dan Kontestasi Sumber Daya Alam Sami Indigenous Movement And Natural Resource's Contestation. Jurnal Kajian Wilayah, 8.

McAdam, Doug, Sidney Tarrow, C. T. (2002). The Dynamic of Contentious. Cambridge University Press. 
Mirsel, R. (2004). Teori Pergerakan Sosial: Kilasan Sejarah dan Catatan Bibliografis.

Moleong, L. J. (2012). Metodologi Penelitian Kualitatif.

Monalu, D. (2007). gerakan sosial dan perubahan kebijakan publik kasus perlawanan masyarakat batak vs PT. Inti Indorayon Utama, porsea, Sumatera Barat. Populasi, 1.

Nonstopnews. (2019, March). Sering Kekurangan Air Bersih, WargaBayah Tanamn Pohon di Sekitar Pabrik Semen Merah Putih. Nonstopnews.Id.

Rachel farakhiyah, M. I. (2019). Eksistensi Masyarakat Adat Tergerus Oleh Kebutuhan Zaman Studi Analisis Konflik Masyarakat Adat Sunda Wiwitan di Kuningan yang Terusir dari Tanah Adatnya Sendiri dengan Teori Identitas. JURNAL KOLABORASI RESOLUSI KONFLIK, 1.

Ramadhan, G. (2018). Identitas dan Gerakan Sosial di Rumpin: gerakan petani dalam konflik pertanahan (studi kasus konflik tanah antara petani rumpin dengan TNI AU di Bogor). Jurnal Polinter Prodi Ilmu Politik Fisip UTA'45 Jakarta, 3.

Regus, M. (2011). tambang dan perlawanan rakyat: studi kasus tambang di manggarai NTT. Lab Sosio Universitas Indonesia, 16.

Rizky agus harnanto, Atika ishmatul ummah, Elsya rekavianti, A. ratnasari. (2018). Gerakan Masyarakat Kendeng, Rembang untuk Keadilan dan Penegakan Hak Asasi Manusia. Jurnal Sosiologi Walisongo, 2. https:/ / doi.org/10.21580/jsw.2018.2.1.2270

Robbins, P. (2012). Political Ecology: A Critical Introduction. Wiley-Blackwell.

Safitri, N. (2011). Masalah Sosial Dan Konflik Masyarakat Adat Papua Dengan Pt Freeport Indonesia (Tinjauan Antropologis). JURNAL ILMU SOSIAL-FAKULTAS ISIPOL UMA, 4.

Seuhendra, Z. (2015). Menengok Pabrik Semen Rp7,8 Triliun Diatas Laut Banten. Detikfinance. finance.detik.com

Siahaan, V. R. (2020). Politik Lingkungan Indonesia: Teori dan Studi kasus (1st ed.). UKI Press.

Tarrow, S. (1998). Power in Movement, Social Movements and Contentius Politics. Cambridge University Pres.

Taylor, W. D. (2000). The Rise of the Environmental Justice Paradig Injustice Framing and the Social Construction of Environmental Discourse. University! Of! Michigan.! American! Behavioral! Scientist, 43.

Wilujeng, P. restu. (2017). Girls Punk: Gerakan Perlawanan Subkultur Di Bawah Dominasi Maskulinitas Punk. Dialektika Masyarakat: Jurnal Sosiologi, 1. 